\title{
Common currency, common identity? The impact of the Euro introduction on European identity
}

Fedra Negri, Department of Social and Political Sciences, Università degli Studi di Milano, Milano, Italy.

Francesco Nicoli, Department of Public Governance and Management, Ghent University, Ghent, Belgium.

Theresa Kuhn, Department of Political Science, University of Amsterdam, Amsterdam, Netherlands.

Pre-print on European Union Politics. https://doi.org/10.1177/1465116520970286

\begin{abstract}
Does European state building go hand in hand with European nation building? This article engages with the scholarly debate on the dynamic relationship between the construction of supranational political institutions that exert key functions of sovereignty and collective identities by investigating the extent to which the adoption of the Euro as a currency is associated with a decrease in the share of Europeans who identify exclusively with their nation and not with the European Union. In detail, by using a dynamic panel-data model on 26 European Union countries in the post-Maastricht period (1996-2017), our results show that the Euro has fostered European identity, leading to a small but significant decrease $(-3 \%)$ in the share of Europeans with exclusive national identity.
\end{abstract}

Keywords: Core state powers, Euro, European identity, European Union, political institutions.

Corresponding author: Fedra Negri, Department of Social and Political Sciences, Università degli Studi di Milano, Via Conservatorio 7, 20122, Milano, Italy. E-mail: fedra.negri@unimi.it. 


\section{Introduction}

'To millions of European citizens, the Euro notes and coins in their pockets make Europe tangible and visible in everyday life as never before. The Euro will thus become a key element in their sense of shared European identity and common destiny'.

Romano Prodi ${ }^{l}$

Does state building go hand in hand with nation building? European integration, as a project of political unification in fieri, seems a good test bed to investigate the relationship between institutions and identity construction. Over the past few decades, the European Union (EU) has acquired important powers in policy areas that are intrinsically linked to national sovereignty (Genschel and Jachtenfuchs, 2018). Indeed, since its beginning, the supranational Court of Justice of the European Union (CJEU - 1952) and the EU Customs Union (1968) have been considered the first building blocks of a set of European core state powers. More recently, the Schengen Area (1985) and the Euro (launch in 1999; currency changeover in 2002) have pushed European integration further. In contrast, political loyalties of European citizens largely remain wedded to the national level (Hooghe and Marks, 2009). While this discrepancy between supranational institution building and collective identities is puzzling, it might simply reflect the slow-changing nature of collective identities.

This article contributes to the scholarly debate on the dynamic relationship between supranational institution building and collective identities by investigating the extent to which the introduction of the Euro as a currency is associated with a decrease in the share of Europeans who identify exclusively with their nation and not with the EU. Among the several steps of EU integration, the introduction of the Euro appears to be our best option to study the relationship between institutions and identity building for several reasons. From a theoretical point of view, a common currency is a key element of sovereignty (Genschel and Jachtenfuchs, 2018), and it represents a highly symbolic issue (Calligaro, 2013; Helleiner, 2003). As Risse (2003: 487) put it, '[w]e miss the significance of the advent of the Euro for European political, economic, and social order if we ignore its identity dimension'. A common currency is one of the most visible 'identity markers' (Risse, 2010) that 
shapes the EU as a taken-for-granted social fact (McNamara, 2015) and helps in building an imagined community (Anderson, 1991). In other words, the Euro helps make the European society real in people's minds. Moreover, a new currency deeply affects the daily lives of all Europeans as they engage in exchanges, purchases, and interactions. For example, the Schengen Area especially affects those individuals who are ex ante more likely to travel abroad (Kuhn, 2015). From an empirical point of view, the introduction of the Euro allows us to focus on a time span in which data are available both in terms of opinion polls on European identity - our dependent variable - and in terms of known confounders. Finally, the common currency - having been adopted only by a subgroup of European countries - allows us to assess, in principle, the extent to which European identity would have evolved - ceteris paribus - in the countries of the Eurozone if these countries had not adopted the Euro (i.e. the counterfactual).

In this article, we investigate the relationship between the introduction of the Euro and European identity through parametric model specifications on 26 EU countries observed from 1996 to 2017. To our knowledge, the geographical and temporal coverage of this observational study makes it the most comprehensive investigation on the dynamic relationship between the Euro changeover and European identity so far. In detail, we hypothesise that, everything else equal, the introduction of the Euro is associated with a lower share of respondents who report an exclusive national identity $(H 1)$ and that this negative relationship increases over time $(H 2)$.

Our results strongly support the first hypothesis: the introduction of the Euro has a modest in magnitude, but significant and robust effect on European identity as the share of people who identify exclusively with their nation decreased by about 3 percentage points after the currency changeover. However, we find no support for $\mathrm{H2}$ : the introduction of the Euro exhausts its negative effect on the share of respondents who identify only with their nation in the short term. 


\section{Collective identities and core state powers}

Collective identities are an essential feature of politics, leading individuals to consider themselves on the basis of ' $[\ldots]$ large and potentially important grouped differences, e.g. those defined by gender, social class, age or ethnicity' (Kohli, 2000: 117).

Scholars agree that collective identities have multiple dimensions and usually distinguish between a cognitive, evaluative, and affective dimension (Hogg, 2006). While the evaluative dimension refers to who, based on which criteria, is part of the collective, the cognitive dimension refers to selfidentification, and the affective dimension refers to feelings of attachment to that collective (see Cram, 2012; Kuhn and Nicoli, 2020). Importantly for the context of the EU, collective identities can be multilevel (Díez Medrano and Paula Gutiérrez, 2001; Risse, 2010) as narrower identities may be nested in overarching ones (Aksoy and Hadzic, 2019). This means that a European identity does not necessarily have to be detrimental to national identity but that the two can co-exist next to each other. Either way, collective identities refer to the responsibility that individuals belonging to a given group feel towards each other and are therefore considered fundamental components in the formation of the nation-state. Such feelings of belonging and allegiance may have different sources, which in turn determine different types of collective identity: for instance, scholars differentiate between civic and ethnic/cultural identity (Bruter, 2005; Kunovich, 2009).

Institutions, then, embody and formalise these links to mutual responsibility arising from belonging. In modern times, the nation-state has surged to be one of the most efficient mechanisms for the construction, deployment, and fostering of group solidarity by establishing institutions that exert collective sovereignty and ensure compliance with social norms. The means through which sovereignty is exerted - and therefore social compliance, mutual responsibility, and mutual solidarity are achieved - have been referred to as 'core state powers' (Genschel and Jachtenfuchs, 2016).

The EU has not refrained from integrating key functions of sovereignty. As Genschel and Jachtenfuchs put it, 'most integration activities since the 1990s concern the integration of core resources of sovereign government' (2018: 179). Among them, the CJEU, the EU Customs Union, 
free movement of goods, capital, services, and labour, the single currency, taxation, labour market and social policies, and - to a lesser extent - diplomatic services and foreign defence. Naturally, not all of these key functions of sovereignty are equally far along on the path of integration. While the CJEU (Saurugger and Terpan, 2019), the EU Customs Union, internal free movement, and the single currency are nowadays powers that mainly pertain to the EU, national governments largely control taxation, labour market and social policies (Menz, 2019), diplomacy, and defence.

\section{The Euro as identity ma(r)ker}

The Euro had been in the making for almost thirty years (early discussions on the Monetary Union began in 1970 with the Werner report). Such a prolonged period of development was the result of divergent forces (Risse et al., 1999). On the one hand, strong functional spill-overs stem from the need of having, within a single market, a degree of coordination of monetary policies. On the other hand, for the large part of the $20^{\text {th }}$ century, monetary policy was intimately connected with fiscal and social policy. Controlling the monetary policy of a nation-state implies exerting control over its internal redistributive decisions. In light of this, it has been argued that the Euro was introduced in a window of opportunity in which the failure of Neo-Keynesian economics in the 1980s and the ensuing change of paradigm towards neoliberal economics made the control of inflation the primary and temporarily uncontested goal of monetary policy (McNamara, 2002). Accordingly, monetary integration was achieved in the only historical moment when it was perceived as having a regulatory, rather than a redistributive, function (Majone, 1999).

From the onset, the Euro was intended to be more than a mere instrument for economic exchange. Its introduction aimed to provide a symbol of collective identity (Calligaro, 2013; Hymans, 2004; McNamara, 2003) that could be tangibly experienced not only by national and European political élites (Risse, 2003), but also by a wider audience of European citizens.

How could the introduction of the common currency lead to a common identity? While there are obvious differences between European integration of core state powers in the $20^{\text {th }}$ and $21^{\text {st }}$ century, 
and the development of nation-states in the $19^{\text {th }}$ century (Saurugger and Thatcher, 2019), existing literature on how state building has helped in forging national identities is informative. Based on this literature, we can identify three general pathways through which the introduction of the Euro could foster a European identity.

First, the literature on nation building has highlighted the important role of public goods provision in creating the conditions for the emergence of feelings of loyalty and attachment among the public (Wimmer, 2018). In this regard, some researchers have seen the Euro as a prime example of 'hybrid' public good (Collignon, 2017) since it constitutes 'a clear case of a common resource good, which is limited in supply but accessible for all' (Collignon, 2017: 45). In turn, Collignon argued that the allocation and distribution dilemmas, as well as the externalities, posed by sharing a currency create the conditions (and the necessity) for the emergence of a European populus on the grounds of citizens' civic equality. Thus, the citizens should be enabled to make 'political decisions about the orientations of the administration of European public goods [...] together, as they are all collective owners of these goods' (Collignon, 2017: 67). Further on this point, others have found a positive relationship between Eurozone membership and trust in EU institutions, net of macro-economic performance (Foster and Frieden, 2017: 519).

Second, historically, central institutions have played an important role in facilitating and increasing communication by providing the necessary conditions for increased cross-territorial interactions among ordinary citizens (Deutsch, 1953). For example, Weber (1976) argued that, among other things, the establishment of national railways in the $19^{\text {th }}$ century helped to convert ordinary 'peasants into Frenchmen'. This same mechanism of increased interactions is also expected to foster supranational identities in the EU (Checkel, 2016; Deutsch et al., 1957; Kuhn, 2015; Recchi and Favell, 2009). The introduction of a common currency significantly improved the conditions for trade, cross-border (online) shopping and other forms of economic transactions within the Eurozone and likely helped to proliferate them. 
Third, political élites may deploy (and have, historically, deployed) ‘top-down’ identity programmes aiming to strengthen the individual sense of belonging to a community. Usually, these identity programmes promote common symbols, heritage, cultural traditions, language, or religion, which have been found to be key drivers of the formation of modern national identities (e.g. Weber, 1976: 297-303; see also McNamara, 2015). In this regard, a common currency is an important 'identity marker' that nation-states have been using to legitimise their power and strengthen the imagined community (Helleiner, 2003; Hymans, 2004). European policy makers have placed high hopes in the symbolic power of the Euro to build a European identity (Calligaro, 2014; Shore, 2013).

On these grounds, we formulate our hypotheses. We move from the well-established idea that individuals hold multiple (Kohli, 2000: 116), nested (Díez Medrano and Gutiérrez, 2001), and partially overlapping (Risse, 2005: 296; see also Aksoy and Hadzic, 2019) identities. We recognise that these identities have both a civic and a cultural component (Bruter, 2003) and that individuals experience their identities in different spheres, insofar as their belonging to the group is grounded both in cognitive and affective processes (Ceka and Sojka, 2016). Thus, strong national identities do not necessarily have to be detrimental to European integration as they do maintain an element of inclusiveness. People's attachment to their nation and the EU at the same time (i.e. cumulative national identity) is fully compatible with pro-integration preferences (Bruter, 2003; 2004; Citrin and Sides, 2004; Hooghe and Marks, 2005), whereas people's attachment only to their nation and not to the EU (i.e. exclusive national identity) is an obstacle to European integration. Coherently, we focus on those citizens who identify only with their nation (i.e. those who do not report any degree of attachment to the EU).

H1: Everything else equal, the introduction of the Euro is associated with a lower share of respondents who report an exclusive national identity (baseline hypothesis).

Second, it is reasonable to expect that, if the integration of a core competence of sovereignty, such as the introduction of the Euro, influences collective identities, then this does not simply happen from one day to the next, but it is constructed over time. 
H2: Everything else equal, the negative effect of the introduction of the Euro on the share of respondents who report an exclusive national identity increases over time (progressive construction hypothesis).

\section{Data and model specifications}

The empirical analysis adopts a European-wide perspective and focuses on macro determinants. We combine Eurobarometer survey data (Mannheim Trend File from 1996 to 2002 and Eurobarometer waves from 2003 to 2017) with macro-economic indicators from Eurostat. Our units of analysis are 26 EU member states, observed in the post-Maastricht period from 1996 to 2017. The six founding countries, as well as Austria, Denmark, Finland, Greece, Ireland, Portugal, Spain, Sweden and the United Kingdom (UK), were observed from 1996 to 2017; and Bulgaria, the Czech Republic, Estonia, Hungary, Latvia, Lithuania, Malta, Poland, Romania, Slovakia, and Slovenia were observed from 2004 to 2017. Notice that Bulgaria and Romania entered the EU in 2007, but Eurostat provides data on these countries from 2004. Cyprus and Croatia are excluded due to missing data on the dependent variable. The UK is included as it was a member state in the sample period.

\section{Operationalisation}

As discussed in the previous sections, collective identification is inherently a multidimensional phenomenon that touches upon different spheres of one's relationship with his or her community. While in principle it is preferable to analyse different dimensions and types of European identity, data availability restricts our analysis to one specific measure of European identity, built upon a survey item asking the respondents to indicate whether they see themselves as 'only [national]', '[national] and European', 'European and [national]', and 'European only'. There are both substantive and practical reasons for this choice, which nonetheless has limitations discussed in the conclusions. Substantively, the question refers to cognitive aspects of collective identity (Cram, 2012) and allows us to capture the degree of exclusiveness of identity, which is the key feature in our understanding of 
the relationship between institutional build-up and identification. Previous research has established that the most important dividing line in collective identities in the EU is between individuals who have some form of European identification and those who exclusively identify with their nation (Fligstein, 2008; Risse, 2010). In practice, using this question also allows us to build a considerably long-term series with sufficient data points to allow for an assessment of the pre- and post-Euro introduction in a sufficient number of countries, a key design feature required to answer the underlying question of this article. Thus, our dependent variable, labelled Exclusive national identity, contrasts respondents who identify only with their nation with respondents who identify also and only with the EU. This variable is clearly closer to the cognitive dimension of identity since respondents must categorise themselves as members of collective groups (i.e. the nation, the EU, or both) according to latent prototypical elements (Hogg, 2006). Even though our variable of choice does not directly discriminate between cultural and civic components of European identity, we follow Bruter (2003), who found that European identity is predominantly civic. Furthermore, since the political systems of the EU and its member states are closely intertwined and connected to each other, we build on the same logic displayed in Bruter's work (2003: 25) to argue that when an exclusive national identity exists in opposition to a European one (as captured by our dependent variable), then it is likely to be cultural in nature. In fact, due to the interlinked nature of Europe's multilevel polity, any genuinely civic national identity would, today, incorporate some degree of multilevel identification with Europe.

\section{[Figure 1 about here]}

Figure 1 displays the share of Eurobarometer respondents who reported an exclusive national identity by country group over the sample period. Overall, their share ranged between $13 \%$ (Luxembourg in 2016 and 2017) and 72\% (UK in 2010). The mean value of Exclusive national identity was 44\% (horizontal grey reference line). Compared to the full sample average (44\%, grey solid line) and to the countries that introduced the Euro in 2002 (41\%, dashed line), the share of respondents with exclusive national identity is systematically higher in the member states that entered the EU in 2004 
and 2007 and adopted the Euro between 2007 and 2015 (46\%, dash-dotted line) and in those that did not adopt the single currency (49\%, dotted line). It is worth noting that the share of respondents who exclusively identify with their nation increased in all countries between 2005 and 2010, years characterised by both the rejection of the Treaty Establishing a Constitution for Europe in France (May 2005) and the Netherlands (June 2005) and the Euro-crisis. However, from 2010 to 2014 - the years of the debt crisis - the share of respondents who identify exclusively with their nation decreased. Our main independent variable of interest refers to the introduction of Euro banknotes and coins, the visible deployment of a centralised core state power. It is operationalised through a dummy variable, called Euro adoption, equal to 0 from 1996 to the year before the currency changeover and 1 from the year of the currency changeover until 2017. All currency changeovers occurred in January. Euro banknotes and coins were distributed in the majority of the countries covered by this study (i.e. 12 countries) in 2002, in Slovenia in 2007, in Malta in 2008, in Slovakia in 2009, in Estonia in 2011, in Latvia in 2014, and in Lithuania in 2015. The Euro still has not been adopted in Bulgaria, the Czech Republic, Hungary, Poland, Romania, and Sweden, even though these countries will join the Eurozone once they have met the necessary conditions. ${ }^{2}$ In contrast, Denmark and the UK negotiated an opt-out from the single currency. This dummy variable allows us to test both $H 1$ and $H 2 .^{3}$

Since the Euro is assumed to influence the economies of its adopting member states, it is important to control for macro-economic conditions so that our estimates are not biased by the Euro's side effects on European identity through the economic channel. Thus, our model specifications control for the Unemployment rate as a proxy for the perceived economic distress; Trade openness, measured as imports plus exports as percentage of gross domestic product (GDP), to account for each country's degree of economic internationalisation; and Economic divergence, which measures the distance of a country's GDP growth rate from the EU average to capture business cycles synchronisation. Furthermore, national governments' ability to ensure good management of public finances is operationalised through the Fiscal balance, which is the difference between a government's revenues 
and expenditures as a ratio of GDP, and through the National debt as a ratio of GDP. For the same purpose, the dummy variable Debt crisis takes the value of 1 from 2010 to 2014 and 0 otherwise.

Last, we control for the educational composition of a country population operationalised as the shares of middle (ISCED categories 3-4) and highly (ISCED categories 5-8) educated individuals according to the harmonised International Standard Classification of Education (ISCED) because education has been consistently found to be a determinant of European identity (Fernandez and Eigmuller, 2018) and EU support. Descriptive statistics are provided in the Online appendix.

\section{Model specifications}

The full, unbalanced panel dataset contains 484 repeated observations of 26 member states. According to their year of accession to the EU and to data availability, countries were observed from 1996 (15 countries) or 2004 (11 countries) to 2017.

The ideal research design to assess the effect of the adoption of the Euro on European identity would have been a quasi-experiment. One candidate would have been the synthetic control method (Abadie et al., 2015), a technique that compares the treatment group (i.e. the EU countries that adopted the Euro) to a synthetic ('fictional') control group given by a weighted combination of untreated cases (i.e. a weighted combination of the EU countries that did not adopt the Euro). However, to apply this technique, a large donor pool would be required to build a proper synthetic counterfactual. In our case, the only countries that had been EU members for long enough before the 2002 currency changeover but did not adopt the Euro were Denmark, Sweden, and the UK. Thus, the synthetic counterfactual would have been too weak.

Because of this, we resort to two alternative model specifications. In detail, we test $H I$ through the Arellano-Bond estimator (Arellano and Bond, 1991), and $H 2$ through an Error Correction Model (ECM) (Beck, 1992). In what follows, we justify this choice.

First, the Arellano-Bond estimator is a linear dynamic panel-data model in which the unobserved panel-level effects are correlated with the lags of the dependent variable. It is especially suitable in 
this research design as, even though we believe that identities change over time, it is reasonable to assume that they do so at a slow pace, whereby individuals slowly adapt to new contexts. If this assumption holds, then we expect the level of Exclusive national identity - our dependent variable in a given country in the year $t$ to be strongly correlated with its lagged values. Indeed, the correlation between Exclusive national identity in the year $t$ and its value in the year $t-1$ is staggeringly high $(0.9$ - p-value $=0$ ), suggesting that this time series changes very slowly over time and that controlling for path dependence is necessary.

Usually, this goal is achieved by adding the lag dependent variable to the right side of the equation. However, when the lagged dependent variable is included among the regressors, traditional paneldata models - like the fixed- or random-effects estimators - are likely to generate biased estimates as they suffer from a specific form of correlation - known as Nickell's Bias (Nickell, 1981) - between the independent variables and the error term. The magnitude of such a bias fundamentally depends on the relationship between the time dimension and the panel dimension of the dataset. The larger the time dimension in respect to the panel dimension, the less significant the bias is. However, the bias is certainly relevant when the time dimension is smaller than the panel dimension. In our case, the time dimension ranges from 22 years (for 15 countries) to 14 years (for 11 countries), while the panel dimension is equal to 26 countries. It follows that, given the nature of our dataset, the Arellano-Bond estimator is expected to perform better than traditional fixed- or random-effects estimators as it accounts for autocorrelation. Crudely put, it relies on the lags of the dependent variable to instrument it, thus returning unbiased estimates (i.e. not correlated with the error term).

Two conditions should be met for the Arellano-Bond estimator to work. First, the hypothesis of autocorrelation in the idiosyncratic errors must be rejected for orders of autocorrelation higher than one. Models 1A and 1B, listed in Table 1, fulfil this condition (i.e. the Arellano-Bond test rejects the null hypothesis of no autocorrelation of order 1 and cannot reject the null hypothesis of no autocorrelation of order 2; p-values are reported in Table 1). 
A second issue concerns the number of instruments generated by the model itself from the lagged values of the dependent variable. If no restrictions are imposed, the model is at risk of overspecification (Roodman, 2009). Hence, we decide to constrain the number of instruments to the minimum of one. The Sargan test cannot reject the null hypothesis of valid over-identifying restrictions, thus supporting our choice (p-values are reported in Table 1).

Considering this discussion, Models $1 \mathrm{~A}$ and $1 \mathrm{~B}$ in Table 1 test $H 1$ through the dummy variable Euro adoption by using the Arellano-Bond estimator, inclusive of one lag of the dependent variable. Further, we expect its coefficient to be negative and statistically significant. Models $1 \mathrm{~A}$ and 1B contain the same variables. They differ only in the estimation of the variance-covariance matrix: Model 1A uses the Windmeijer bias-corrected (WC) robust estimator (2005); Model 1B uses the conventionally derived variance estimator for generalised method of moments estimation.

Instead, the statistical test of $H 2$, according to which the negative effect of the introduction of the Euro on the share of respondents with exclusive national identity is expected to increase over time, requires an estimator that can disentangle the short-term and the long-term effects of the Euro. Thus, we resorted to an ECM, an estimator developed by Beck (1992) that regresses the change in the dependent variable on its lagged level, the lagged level of each potential co-integrating factor, and whatever other levels or differences theory or empirics may suggest. Provided that the coefficient of the lagged dependent variable in levels is negative - a condition that Model 2 in Table 2 fulfils - this approach provides valid estimates.

Using the ECM structure, the estimated coefficients of differenced independent variables refer to the momentum-like, short-run relationship between changes in independent and dependent variables. Instead, the estimated coefficients of independent variables in levels refer to equilibrium-like, longrun relationships between levels. Moreover, long-term effects dissipate over time through the coefficient on the lagged dependent variable, reflecting rates of adjustments of levels to equilibrium relationships (Franzese, 2002). 
In the present application, all the independent variables may have both short- and long-term effects. For this reason, they enter the regression in current changes and lagged levels. The short-term effect of the Euro on the share of respondents who exclusively identify with their nation is measured by the estimated coefficient of the variable Euro adoption in first difference and, in light of $H 1$, we expect it to be negative and statistically significant. More interestingly, according to $H 2$, the long-term effect of the Euro on the share of people with exclusive national identity is captured by dividing the estimated coefficient of the variable Euro adoption in levels - that we expect to be negative and statically significant - by the estimated coefficient on the lagged dependent variable, labelled 'error correction rate'. As suggested by Beck and Katz (1995), panel-corrected standard errors are used to correct for panel heteroscedasticity in the data structure.

\section{Results}

Models $1 \mathrm{~A}$ and $1 \mathrm{~B}$ in Table 1 tested our baseline hypothesis $(H 1)$ by reporting the estimated effect of the currency changeover on the share of people with exclusive national identity, controlling for several macro-economic dynamics.

Supporting our expectations, the results indicate that the adoption of the Euro is associated with a modest in magnitude but statistically significant reduction of the share of people who identify only with their nation: in detail, everything else equal, the adoption of the Euro is associated with a decrease in the share of people with exclusive national identity of about 3 percentage points.

\section{[Table 1 about here]}

It could be questioned whether an effect of -3 percentage points is large enough to claim that the Euro has had a positive effect on the European identity. A look at the other estimated coefficients provides a partial answer. On the one hand, the Euro adoption dummy seemed to perform quite well when compared to the other economic control variables, whose effects were lower than 1 percentage point or not statistically significant. On the other hand, as pointed out by the tests discussed in the subsection devoted to the model specifications, the best predictor of a country's attitude towards the EU 
is its historical degree of identification with the EU. Even though the Arellano-Bond estimator helps in dealing with autocorrelation by construction by using internal instruments, it is worth noting that the standard deviation of the share of respondents reporting an exclusive national identity within the countries in our sample was equal to 5.7 percentage points. Moreover, across countries and years, their mean value was 44 percentage points. Considering these descriptive statistics, a change of 3 percentage points triggered by the adoption of the Euro is not as negligible as it may seem.

Model 2 in Table 2 tested our progressive construction hypothesis $(H 2)$, according to which the negative effect of the Euro adoption on the share of people who exclusively identify with their nation will become progressively stronger over time, through an ECM.

\section{[Table 2 about here]}

The coefficient of the lagged dependent variable in levels was negative and highly statistically significant, meaning that inferences from Model 2 should be free of unit-root concerns. Moreover, this coefficient suggests that the share of people with exclusive national identity adjusts quite slowly. In particular, $61 \%(1-0.386=0.614)$ of a shock in one year persists into the next, then $61 \%$ of that into the following year, and so forth. Thus, the long-run impact of any permanent shock in the share of respondents who exclusively identify with their nation is about $2.59\left(0.386^{-1}\right)$ times its immediate impact.

Having discussed the error correction rate, we focused on the estimated coefficients of the main independent variable, Euro adoption, which entered the regression both in current changes and in lagged levels. The coefficient of Euro adoption in current changes was negative and statistically significant. Thus, like the estimates of Models 1A and 1B, this suggests that the currency changeover triggered a momentum-like, short-run, negative impact on the share of people who identify only with their nation equal to 3.9 percentage points. Thus, $H 1$ again finds empirical support. However, contrary to our expectation, Model 2 detected a statistically insignificant relationship between Euro adoption in lagged levels and the share of people who identify only with their nation in the long-run. This 
means that $\mathrm{H} 2$ is not supported: the negative effect of the currency changeover on the share of people with exclusive national identity does not increase over time.

Thus, our results demonstrate that the adoption of the Euro affects European identity as it decreases the share of respondents who identify only with their nation by about 3 percentage points $(H 1$ is supported). However, the currency changeover exhausts its negative effects in the short run ( $H 2$ is not supported).

\section{Conclusions}

This article investigates the dynamic relationship between the integration of core state powers at the supranational level and the emergence and strengthening of collective identities by focusing on the introduction of the Euro, the largest-ever currency changeover which began in January 2002 in 12 European countries, as a crucial example of integration of a key function of sovereignty. This choice allowed us to take advantage of Eurobarometer and Eurostat data in 26 EU member states observed in the post-Maastricht period (1996-2017).

We found robust evidence in support of our baseline hypothesis (HI). Indeed, the introduction of the Euro has had a negative and statistically significant effect on the share of respondents who identify only with their nation in the countries that adopted it (about -3\%). This effect was stable across model specifications, both in significance and in magnitude. Thus, our results can help build a bridge to the first study on the relationship between the introduction of the Euro and European identity, published by Risse (2003) shortly after the Euro changeover. He demonstrated that the single currency, being 'a visible link from Brussels to the daily lives of the citizens' (Risse 2003: 501), affected respondents' identification with Europe already in the short run. In fact, by controlling for the temporal dynamics of exclusive national identification, our results suggest that, immediately after its introduction, the Euro became a symbol affecting Europeans' feelings of belonging towards Europe.

Of course, our argument about the capability of the Euro as a supranational institution to affect the degree of collective identification with the EU is weakened by the modest magnitude of the estimated 
effect: the adoption of the Euro decreases the share of respondents who do not report any degree of attachment to the EU by about 3 percentage points. However, it is worth noting that the Euro is not the only supranational institution affecting European citizens' ordinary lives. Thus, there are reasons to believe that, together, European institutions are capable of building and fostering collective identities (see also Saurugger and Thatcher, 2019).

Nonetheless, these results should be taken with a grain of salt. First, our observational and correlational research design was constrained by data availability. As discussed in the section devoted to the model specifications, it would have been preferable to employ a quasi-experimental research design by estimating a synthetic control (Abadie et al., 2015). However, the number of countries that were long-term EU members before the Euro adoption in 2002 but did not join the Eurozone, is simply too limited to appropriately implement this technique. The second-best alternative - namely, individual-level panel data before and after the introduction of the Euro in both Eurozone and nonEurozone countries - was also not plausible: our dependent variable was computed from crosssectional Eurobarometer surveys that make it impossible to fully establish causal relationships. Thus, even though, at the theoretical level, we developed a causal theory on the relationship between institutions and identity building, at the empirical level, data availability constrained us to detecting correlations. However, it is important to note that, in the Online appendix, we checked the robustness of our findings by testing the role of the Euro adoption against that of the abolishment of the border controls due to the Schengen Area. From a merely empirical point of view, these further results allow us to make a stronger and more compelling point on the role of the adoption of the Euro in fostering European identity as the implementation of the Schengen Area has proven to be uncorrelated with the share of Europeans with exclusive national identity.

Second, our model may have suffered from ecological fallacies: while, in absence of an individuallevel panel dataset, country-level estimations represent a viable alternative to assess the effect of policy changes, one should be careful in imposing observed macro-level changes over unobserved 
individual variables. However, the consistency between our large- $\mathrm{N}$ results and those obtained by more detailed studies on a limited number of countries gives us confidence regarding their reliability. Third, we could not exclude a degree of reversed causality. However, at the theoretical level, according to the dynamic perspective embraced here, reverse causality seems minor compared to the previous concerns. In fact, we do not deny, theoretically, the possibility that the Euro was adopted by certain countries because these countries already had a higher share of people who identified with Europe before adopting the Euro. Moreover, at the empirical level, we provided a partial control for reverse causality by adopting model specifications that, by construction, control for autocorrelation. Our statistical analysis suggests that both processes are at work: countries with more inclusive national identities were more eager to adopt the Euro, and in turn Euro adoption had a larger effect on those countries.

Finally, our dependent variable - albeit widely used and, to some extent, linked to different identification processes - mainly captured a cognitive dimension of identification, which a complete study on the identity effects of the Euro introduction should include if the data are available, in addition to a measure of affective identification.

All in all, we contribute to the literature investigating the relationship between core state powers and identities by providing significant evidence in support of the dynamic view: Common identities may stem from the construction of state powers, insofar as these contribute to creating the conditions that allow meaningful social interactions leading to the emergence of a sense of collective belonging. While the lack of common identity is often used as a rhetorical artefact to constrain the construction of supranational institutions (and, increasingly, to deconstruct existing national institutions), this study suggests that integration processes could benefit from effective institutional designs as the latter may be essential factors in the emergence and fostering of a common identity. 


\section{Acknowledgements}

We would like to thank Sander Kunst for providing the dataset, and we are grateful to Thomas Risse, Gerald Schneider and the anonymous reviewers for useful comments on earlier versions of this article. Sven Hegewald provided excellent research assistance. All remaining errors are our own.

\section{Funding}

The authors received no financial support for the research, authorship, and/or publication of this article. 


\section{References}

Abadie A, Diamond A and Hainmueller J (2015) Comparative Politics and the Synthetic Control Method. American Journal of Political Science 59(2): 495-510.

Aksoy D and Hadzic D (2019) Political institutions and collective attachments. European Union Politics 20(4): 584-607.

Anderson B (1991) Imagined Communities: Reflections on the Origin and Spread of Nationalism. New York: Verso.

Arellano M and Bond S (1991) Some tests of specification for panel data: Monte Carlo evidence and an application to employment equations. Review of Economic Studies 58: 277-297.

Beck N (1992) Comparing Dynamic Specifications: The case of Presidential Approval. Political Analysis 3: 51-87.

Beck N and Katz JN (1995) What To Do (and Not To Do) With Time Series Cross-Section Data. American Political Science Review 89(3): 634-647.

Bruter M (2003) Winning Hearts and Minds for Europe: The Impact of News and Symbols on Civic and Cultural European Identity. Comparative Political Studies 36(10): 1148-1179.

Bruter M (2004) On what citizens mean by feeling ‘European': perceptions of news, symbols and borderless-ness. Journal of Ethnic and Migration Studies 30(1): 21-39.

Bruter M (2005) Citizens of Europe? The Emergence of a Mass European Identity. New York: Palgrave Macmillan.

Calligaro O (2013) Negotiating Europe: EU promotion of Europeanness since the 1950s. New York: Palgrave Macmillan.

Calligaro O (2014) From 'European cultural heritage' to 'cultural diversity'? The changing core values of European cultural policy. Politique européenne 3(45): 60-85.

Ceka S and Sojka A (2016) Loving it but not feeling it yet? The state of European identity after the eastern enlargement. European Union Politics 17(3): 482-503. 
Checkel JT (2016) Regional identities and communities. In: Börzel TA and Risse T (eds) The

Oxford Handbook of Comparative Regionalism. Oxford: Oxford University Press: 559-578.

Citrin J and Sides J (2004) More than Nationals: How Identity Choice Matters in the New Europe. In: Hermann RK, Risse T and Brewer MB (eds) Transnational Identities: Becoming European in the EU. Lanham, MD: Rowman \& Littlefield: 161-185.

Collignon S (2017) The European Union as a Republic. In: Collignon S (ed) The Governance of European Public Goods. Cham (CH): Palgrave McMillan: 39-77.

Cram L (2012) Does the EU Need a Navel? Implicit and Explicit Identification with the European Union. JCMS: Journal of Common Market Studies 50(1): 71-86.

Deutsch KW (1953) Nationalism and social communication. An inquiry into the foundations of nationality. Cambridge: The Technology Press.

Deutsch KW, Burrel SA, Kann RA et al. (1957) Political Community and the North Atlantic Area: International Organization in the Light of Historical Experience. Princeton: Princeton University Press.

Díez Medrano J and Gutiérrez P (2001) Nested identities: National and European identities in Spain. Journal of Ethnic and Migration Studies 24(5): 753-78.

Fernández JJ and Eigmüller M (2018) Societal Education and the Education Divide in European Identity, 1992-2015. European Sociological Review 34(6): 612-628.

Fligstein N (2008) Euroclash: The Eu, European Identity, and the Future of Europe. Oxford: Oxford University Press.

Foster C and Frieden J (2017) Crisis of trust: Socio-economic determinants of Europeans' confidence in government. European Union Politics 18(4): 511-535.

Franzese RJ (2002) Macroeconomic policies of developed democracies. Cambridge: Cambridge University Press. 
Genschel P and Jachtenfuchs M (2016) More Integration, Less Federation: The European Integration of Core State Powers. Journal of European Public Policy 23(1): 42-59. Genschel P and Jachtenfuchs M (2018) From Market Integration to Core State Powers: The Eurozone Crisis, the Refugee Crisis and Integration Theory: Crises in Core State Powers. Journal of Common Market Studies 56(1): 178-196.

Helleiner E (2003) The making of national money: Territorial currencies in historical perspective. Ithaca: Cornell University Press.

Hogg M (2006) Social identity theory. In: Burke P (ed) Contemporary Social Psychological Theories. Stanford: Stanford Social Sciences: 111-36.

Hooghe L and Marks G (2005) Calculation, Community and Cues: Public Opinion on European Integration. European Union Politics 6(4): 419-43.

Hooghe L and Marks G (2009) A Postfunctionalist Theory of European Integration: From Permissive Consensus to Constraining Dissensus. British Journal of Political Science 39(1): 1-23.

Hymans JE (2004) The changing color of money: European currency iconography and collective identity. European Journal of International Relations 10(1): 5-31.

Kohli M (2000) The battlegrounds of European identity. European Societies 2(2): 113-37.

Kuhn T (2015) Experiencing European integration. Transnational lives and European identity. Oxford: Oxford University Press.

Kuhn T and Nicoli F (2020) Collective identities and the integration of core state powers. Journal of Common Market Studies 58(1): 1-213.

Kunovich RM (2009) The sources and consequences of national identification. American Sociological Review 74(4): 573-593.

Majone G (1999) The regulatory state and its legitimacy problems. West European Politics 22(1): $1-24$.

McNamara K (2002) Rational Fictions: Central Bank Independence and the Social Logic of Delegation. West European Politics 25(1): 47-76. 
McNamara K (2003): Towards a Federal Europe? The Euro and Institutional Change in Historical Perspective. In: Börzel TA and Cichowski RA (eds) Law, politics, and society (The state of the European Union 6). Oxford: Oxford University Press: 253-268.

McNamara K (2015) The Politics of Everyday Europe. New York: Oxford University Press.

Menz G (2019) Understanding the identity of a policy field: the European Commission and liberal modernization in the domain of labour and social policy. Comparative European Politics 17(4): 603-618.

Nickell S (1981) Biases in Dynamic Models with Fixed Effects. Econometrica 49(6): 1417-1426.

Recchi E and Favell A (eds) (2009) Pioneers of European integration: Citizenship and mobility in the EU. Cheltenham, UK: Edward Elgar Publishing.

Risse T (2003) The Euro between national and European identity. Journal of European Public Policy 10(4): 487-505.

Risse T (2005) Neofunctionalism, European identity, and the puzzle of European integration. Journal of European Public Policy 12(2): 291-309.

Risse T (2010) A Community of Europeans? Transnational Identities and Public Spheres. Ithaca, NY: Cornell University Press.

Risse T, Engelmann-Martin D, Knopf J-K and Roscher K (1999). To Euro or Not to Euro? The EMU and Identity Politics in the European Union. European Journal of International Relations 5(2): 147-187.

Roodman D (2009) How to do xtabond2: An introduction to difference and system GMM in Stata. Stata Journal 9(1): 86-136.

Saurugger S and Terpan F (2019) The EU's legal identities and the Court of Justice of the EU. Comparative European Politics 17(4): 548-566.

Saurugger S and Thatcher M (2019) Constructing the EU's political identity in policy making. Comparative European Politics 17(4): 461-476. 
Shore C (2013) Building Europe: The cultural politics of European integration. London:

Routledge.

Weber E (1976) Peasants into Frenchmen. Stanford: Stanford University Press.

Wimmer A (2018) Nation Building. Why Some Countries Come Together While Others Fall Apart. Princeton: Princeton University Press.

Windmeijer F (2005) A finite sample correction for the variance of linear efficient two-step GMM estimators. Journal of Econometrics 126: 25-51. 


\section{Figures}

Figure 1: Share of people with exclusive national identity by country group over time

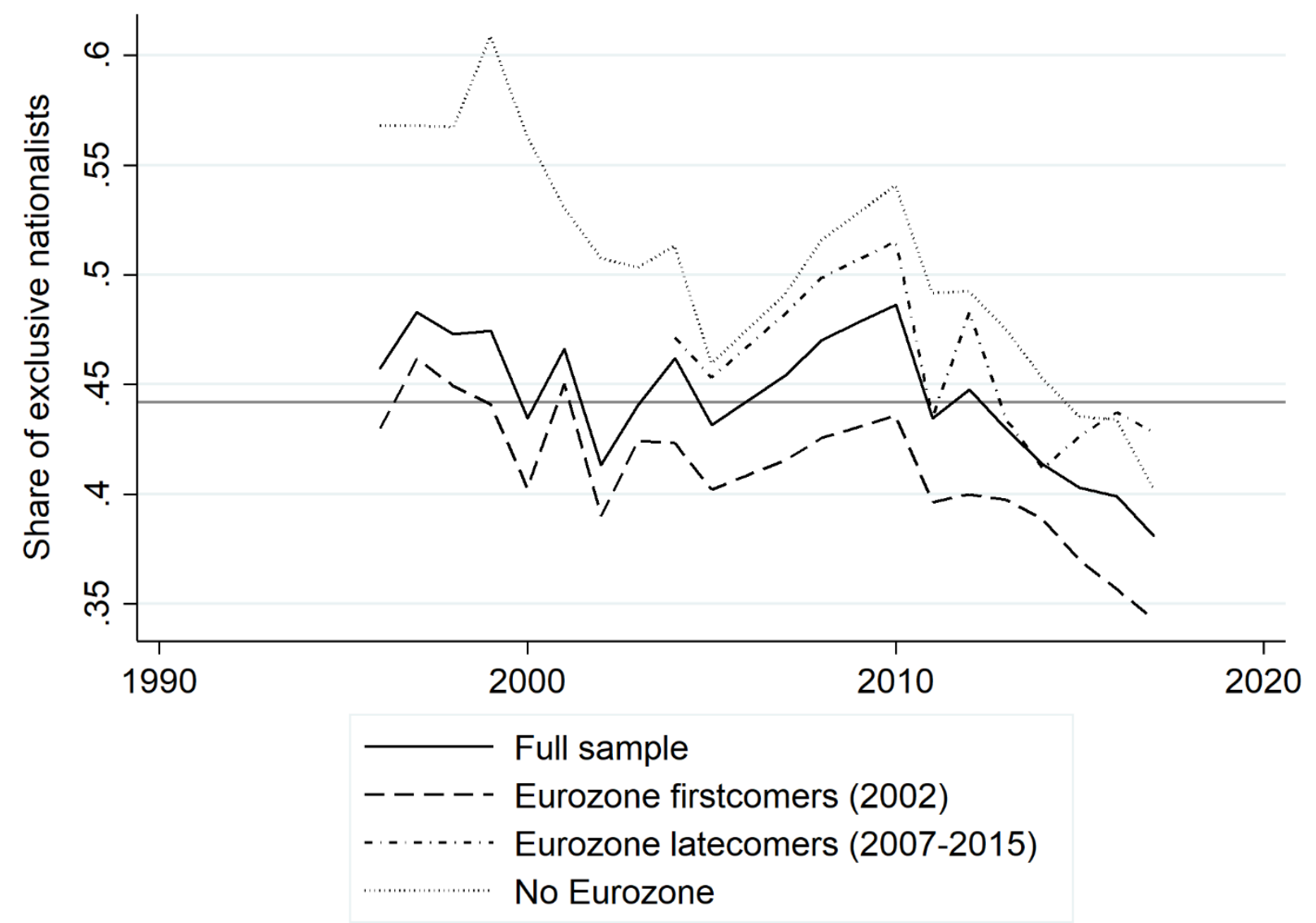

Note: Mannheim Trend File (1996-2002) and Eurobarometer waves (2003-2017). Unweighted by population. 


\section{Tables}

Table 1: Effect of Euro adoption on the share of people with exclusive national identity (ArellanoBond estimator)

\begin{tabular}{lcc}
\hline & Model 1A & Model 1B \\
\hline Excl. national identityt-1 & 0.161 & 0.161 \\
Euro adoption & $(0.126)$ & $(0.037)^{* * *}$ \\
& -0.031 & -0.031 \\
Unemployment rate & $(0.010)^{* * *}$ & $(0.004)^{* * *}$ \\
Debt crisis & -0.002 & -0.002 \\
& $(0.001)$ & $(0.001)^{* * *}$ \\
Economic divergence & 0.008 & 0.008 \\
& $(0.006)$ & $(0.003)^{* * *}$ \\
Fiscal balance & 0.456 & 0.456 \\
& $(0.437)$ & $(0.248)^{*}$ \\
Middle educated & -0.006 & -0.006 \\
& $(0.002)^{* * *}$ & $(0.001)^{* * *}$ \\
Highly educated & 0.000 & 0.000 \\
Trade openness & $(0.002)$ & $(0.001)$ \\
Debt ratio & -0.003 & -0.003 \\
& $(0.002)$ & $(0.001)^{* * *}$ \\
Constant & 0.024 & 0.024 \\
& $(0.047)$ & $(0.019)$ \\
N & -0.000 & -0.000 \\
Arellano-Bond test - Order 1 & $(0.001)$ & $(0.000)$ \\
Arellano-Bond test - Order 2 & 0.434 & 0.434 \\
Sargan test & $(0.100)^{* * *}$ & $(0.034)^{* * *}$ \\
\hline
\end{tabular}

Note: Arellano-Bond dynamic panel-data estimation. Model 1A uses the Windmeijer (2005) WCrobust estimator. Model 1B uses the conventionally derived variance estimator for generalised method of moments estimation. $* p<0.1 ; * * p<0.05 ; * * * p<0.01$ 
Table 2: Long-term effects of Euro adoption on the share of people with exclusive national identity $(E C M)$

\begin{tabular}{|c|c|}
\hline & Model 2 \\
\hline Excl. national identity $\mathrm{t}_{\mathrm{t}-1}$ & $\begin{array}{l}-0.386 \\
(0.056)^{* * *}\end{array}$ \\
\hline$\Delta$ Euro adoption & $\begin{array}{l}-0.039 \\
(0.010)^{* * *}\end{array}$ \\
\hline Euro adoption $_{\mathrm{t}-1}$ & $\begin{array}{l}0.000 \\
(0.006)\end{array}$ \\
\hline$\Delta$ Unemployment rate & $\begin{array}{c}-0.000 \\
(0.002)\end{array}$ \\
\hline Unemployment rate $_{t-1}$ & $\begin{array}{l}0.000 \\
(0.001)\end{array}$ \\
\hline$\Delta$ Debt crisis & $\begin{array}{l}0.003 \\
(0.012)\end{array}$ \\
\hline Debt crisist -1 & $\begin{array}{c}-0.013 \\
(0.010)\end{array}$ \\
\hline$\Delta$ Economic divergence & $\begin{array}{l}0.048 \\
(0.097)\end{array}$ \\
\hline Economic divergence $t-1$ & $\begin{array}{c}-0.044 \\
(0.113)\end{array}$ \\
\hline$\Delta$ Fiscal balance & $\begin{array}{c}-0.001 \\
(0.001)\end{array}$ \\
\hline Fiscal balance $_{t-1}$ & $\begin{array}{l}0.000 \\
(0.001)\end{array}$ \\
\hline$\Delta$ Middle educated & $\begin{array}{c}-0.000 \\
(0.001)\end{array}$ \\
\hline Middle educated $_{\mathrm{t}-1}$ & $\begin{array}{c}-0.000 \\
(0.001)\end{array}$ \\
\hline$\Delta$ Highly educated & $\begin{array}{c}-0.000 \\
(0.001)\end{array}$ \\
\hline Highly educated $_{\mathrm{t}-1}$ & $\begin{array}{l}-0.003 \\
(0.001)^{* * *}\end{array}$ \\
\hline$\Delta$ Trade openness & $\begin{array}{l}0.038 \\
(0.046)\end{array}$ \\
\hline Trade openness $\mathrm{t}_{\mathrm{t}-1}$ & $\begin{array}{l}0.002 \\
(0.025)\end{array}$ \\
\hline$\Delta$ Debt ratio & $\begin{array}{l}0.002 \\
(0.001)^{* * *}\end{array}$ \\
\hline Debt ratiot t 1 & 0.000 \\
\hline Country dummies & Yes \\
\hline Constant & $\begin{array}{l}0.251 \\
(0.048)^{* * * *}\end{array}$ \\
\hline $\begin{array}{l}R^{2} \\
N\end{array}$ & $\begin{array}{r}0.30 \\
458\end{array}$ \\
\hline
\end{tabular}

Note: OLS estimations with panel corrected standard errors in parentheses. Country dummies included. $* p<0.1 ; * * p<0.05 ; * * * p<0.01$ 
${ }^{1}$ Speech 'Three challenges facing Europe' by Romano Prodi, President of the European Commission, to the Council on Foreign Relations, New York, 11 January 2002.

${ }^{2}$ Sweden's Treaty of Accession (1994) made it subject to the Treaty of Maastricht, which obliges countries to join the Eurozone once they have met the necessary conditions. For this reason, the EU pools Sweden with the countries that will join the Eurozone in a near future (see https://europa.eu/european-union/about-eu/euro/which-countries-use-euro_en - accessed 25 May 2020). However, a referendum held in Sweden in September 2003 saw a $55.9 \%$ vote against membership to the Eurozone. Consequently, Sweden decided not to adopt the Euro for the time being. ${ }^{3}$ The operationalization of the main independent variable (IV) Euro adoption comports a drawback insofar as the geographical and temporal scope of the dataset overlaps with other important episodes of integration, such as the Schengen agreement. Since the overlap between the Euro adoption and the entrance into force of the Schengen agreement is not complete, in the Online appendix, we compare the results of the models displayed in Tables 1 and 2, that detect a negative and statistically significant effect of the Euro adoption on the share of Europeans with exclusive national identity, with the results of equivalent models where the main IV captures the elimination of the border controls. The lack of statistical significance of the Schengen IV lends further credibility to the robustness of the results presented in this article. 